\title{
Impact of marble powder amendment on hydraulic properties of a sandy soil**
}

\author{
Mabood Farhadi-Machekposhti ${ }^{1}$, Javier Valdes-Abellan ${ }^{1}$, Concepcion Pla ${ }^{1}$, David Benavente ${ }^{2}$, \\ and Yakov Pachepsky* (i)
${ }^{1}$ Department of Civil Engineering, University of Alicante, Crta. San Vicente s/n. 03690 San Vicente del Raspeig, Alicante, Spain
${ }^{2}$ Department of Earth and Environmental Sciences, University of Alicante, Spain
${ }^{3}$ USDA-ARS, Environmental Microbial and Food Safety Lab., 10300 Baltimore Av., Building 173 Room 203, BARC-East, Beltsville, MD 20705, USA

Received October 18, 2019; accepted February 17, 2020

\begin{abstract}
Marble powder is one of carbonate rock amendments that is used to improve soil reaction. We hypothesized that the powdered marble addition can cause favorable changes in hydraulic properties of sandy soils. Six levels of marble powder addition to an aridisol soil (0\%; M0; 5\%; M5; 10\%; M10; $15 \%$; M15; 20\%; M20 and 25\%, M25; by bulk volume) were analyzed in triplicate. The saturated hydraulic conductivity and soil water retention curves were obtained. Pore space properties were investigated using soil water retention curves, mercury intrusion porosimetry and scanning electron microscopy. The saturated hydraulic conductivity significantly decreased (between 83 and $97 \%$ for M5 and M25 respectively) and parameters $\alpha$ and $n$ of the van Genuchten model significantly decreased in marble-amended soils. Both field capacity and permanent wilting point increased with the addition of marble powder. Plant-available water, increased significantly until $10 \%$ of marble powder application; higher percentages of application did not provide additional significant changes in the plant-available water. Pore space distributions from soil water retention curves parameters showed an increase in the pore size range and a decrease in the average pore size; pore space distribution from the scanning electron microscopy also showed the presence of a new family of dominant pore sizes which was not detected by the soil water retention curves parameters approach. It was concluded that the addition of marble powder can improve the ability of soil to store water providing an advantage for irrigation water management in water scarce environments. Further research will have to address the impact of marble powder amendment under field semi-arid conditions.

Keywords: saturated hydraulic conductivity, soil water retention curve, field capacity, plant available water, pore size distribution
\end{abstract}

*Corresponding author e-mail: yakov.pachepsky@ars.usda.gov **This work was partially funded by the project GRE17-12 from the University of Alicante (2018-2019).

\section{INTRODUCTION}

Plant growth strongly depends on soil which provides mechanical and nutrient support for plants as well as water. Sandy soils have been known as relatively poor plant substrates (Qi et al., 2002), partly due to their hydraulic properties. Sandy soils conduct water fast and have a low plant-available water content. In sandy soils, water can easily transport nutrients and other substances to groundwater thus reducing the irrigation water and fertilizer efficiency and creating environmental issues (Hall and Bell, 2015; Zhang et al., 2016; Porter et al., 2018; Serio et al., 2018; Biddau et al., 2019).

Adding fine particles can change the soil structure and affect soil hydraulic properties (Stone, 1980a, 1980b; Ghodrati et al., 1995; Yunusa et al., 2011). The addition of fine particles to the sandy soil may increase its water-holding capacity. Adding fine material can stabilize sandy soils, which can prevent desert expansion and dust storms, which are important in arid and semiarid environments. Finally, it can increase the available nutrients in the soil (Joris et al., 2013; da Costa and Crusciol, 2016) and improve plant productivity (Olego et al., 2016; Tiritan et al., 2016).

Soil amendments affect the entire spectrum of soil properties, and their effect has to be evaluated in several aspects. One of such aspects is the ability of soil to conduct and retain water. The saturated hydraulic conductivity and soil water retention curve (SWRC), are the soil hydraulic properties to be evaluated. Other soil properties, such as the plant-available water, the wilting point or the field capacity,

(C) 2020 Institute of Agrophysics, Polish Academy of Sciences 
can be inferred indirectly from the abovementioned SWRC data. The importance of these parameters in the agricultural water management is out of doubt.

There is a long history of sandy soil amendment studies, but the interest in the scientific community is far from decline. Eibisch et al. (2015) used pyrochars and hydrochars, and they revealed that soil hydraulic properties improved and plant available water increased. Volk et al. (2016) investigated the effect of a soil-grown biofilm on the sandy soil's hydraulic properties. Their results showed that, compared to the sandy soil, the amended soil had a stronger soil water retention. They also found that biofilm reduced the saturated hydraulic conductivity of the soil. Amoakwah et al. (2017) examined the effect of adding corn cob biochar to sandy loam soil. Their results indicated that the application of $20 \mathrm{t} \mathrm{ha}^{-1}$ of biochar significantly increased soil water retention. Basso et al. (2013) reported that amending sandy soil with biochar increased its water-holding capacity. Auler et al. (2017) evaluated the liming effects on silty clay soil and reported that the addition of lime to the soil increased both the field capacity (FC) and the permanent wilting point (PWP), respectively. They also reported that the plant-available water content, PAW, assumed as the difference between FC and PWP, also increased. Barnes et al. (2014) studied the effect of biochar addition to sandy soil. They reported that in amended sandy soil, saturated hydraulic conductivity decreased by $92 \%$. Banedjschafie and Durner (2015) devised an experiment to study the effect of superabsorbent polymers addition to sandy soil. They revealed that with the addition of super absorbents, the plant-available water content increased.

Powdered carbonaceous rocks and shells are commonly used as soil amendments (Barros et al., 2009; Remonsellez et al., 2017; Holland et al., 2018; Ratke et al., 2018). One of such amendments is the marble powder that is generated as an industrial byproduct that results from the mining, sawing, shaping and polishing of marble (Brown et al., 1959; Ashish, 2018; Khodabakhshian et al., 2018). Using marble powder as a soil amendment also offers a solution of the environmental problems related to marble industrial waste disposal (Wang et al., 2017; Ashish, 2018). Marble powder as soil amendment has been studied (e.g., Marras et al., 2010; Zumrawi and Abdalla, 2018), but the main objective has been to improve soil geotechnical characteristics. To the best of our knowledge, the effect of marble additions to sandy soil and its effect on soil hydraulic properties has not been studied so far. Therefore, the objective of the present work is to study the effect of marble addition to sandy soil on the soil hydraulic properties at the laboratory scale.

\section{MATERIAL AND METHODS}

Sandy aridisol soil was collected in an experimental plot that is located in the foothills of a calcareous relieve in the region of Alicante, Spain (38 $\left.37^{\prime} 10.8^{\prime \prime} \mathrm{N} 0^{\circ} 49^{\prime} 20.2^{\prime \prime} \mathrm{W}\right)$. Undisturbed samples in $8-\mathrm{cm} \varnothing$ steel rings were collect- ed at the 30-cm depth; additional disturbed samples were collected at the same depth. Marble powder was collected from one of the waste sites in the municipality of Novelda, Spain $\left(38^{\circ} 25^{\prime} 52.2^{\prime \prime} \mathrm{N} 0^{\circ} 46^{\prime} 48.4^{\prime \prime} \mathrm{W}\right)$.

The bulk density (Grossman and Reinsch, 2002) and mean total porosity (Flint and Flint, 2002b) were determined for the sandy soil; the particle size distribution (Gee and Or, 2002) and soil particle density (Flint and Flint, 2002a) were determined for both the sandy soil and the marble powder. The mineralogical composition of soil and marble powder were obtained analyzing crushed samples $(<63-\mu \mathrm{m}$ size) with powder X-ray diffraction (XRD) by using a D8-Advance diffractometer (Bruker, Germany) with a Goebel mirror (nonplanar samples) using $\mathrm{Cu} \mathrm{K} \alpha$ radiation. The scanning range was from $2 \theta=1$ to $80^{\circ}$. Data were collected and interpreted using XPowder $\odot$ software v.12 (Martin Ramos, 2004). The semi-qualitative search-matching procedure was based on the ICDD-PDF2 database. The analysis of trace elements in the marble powder was carried out to detect the potential presence of heavy metals and compare them with standards for plant growing media according to the European Commission decision 2015/2099. The heavy metals concentration analysis was performed with ICP-MS after an acid digestion, which uses combination of hydrochloric, nitric, perchloric and hydrofluoric acids. The marble industry produces water solution with the marble powder suspended and it uses chemical products to accelerate the sedimentation process so the presence of heavy metals in the marble powder should not be disregarded.

The original soil (M0, $0 \%$ of marble) and the soil with five different levels of marble addition $(5 \%, \mathrm{M} 5 ; 10 \%$, M10; 15\%, M15; 20\%, M20 and 25\%, M25; by bulk volume) were employed in this study, yielding 6 treatments. We maintained the porosity equal to $35 \%$ to define the different levels of mixtures; e.g., $5 \%$ mixture means that $5 \%$ of the solid phase volume was a substitute by the same volume of marble powder. Small differences in the bulk density existed because of the difference in particle density between the marble power and the sandy soil particles. The original sandy soil was air-dried, $<2 \mathrm{~mm}$ sieved, and used to create three replications for each mixture level.

Marble powder was mixed manually with the sandy soil for each sample. Each sample was packed into $250 \mathrm{~cm}^{3}$ stainless steel cylinders $(5 \mathrm{~cm}$ height and $8 \mathrm{~cm}$ diameter). To achieve uniform bulk density, the soil samples were packed with consistent force in five equal increments. To make sure that the samples were homogeneous after adding each fifth of the sample to the cylinder, the remaining soil was mixed again before adding the next fraction.

Soil and soil-marble powder mixtures in cylinders were saturated from bottom to the top. The saturated hydraulic conductivity $\left(K_{\mathrm{s}}\right)$, was obtained in the laboratory using the KSAT apparatus (UMS ${ }^{\circledR}$ company) under the falling head condition. 
Next, the soil water retention curve, SWRC, data was obtained using Hyprop (UMS® company). Hyprop measures the soil water content and the pressure head between saturation and the air entry value by using the extended evaporation method (Schindler et al., 2010a,b). The tensiometer shafts and the sensor unit were filled with deionized and degassed water. The evaporation experiments were initiated at $\mathrm{h}=0 \mathrm{~cm}$ pressure head at the top of soil sample.

The saturated samples were placed on the Hyprop device and were exposed to evaporation in the laboratory. The evaporation process was accelerated by using a fan. The experiments were conducted at the room temperature ranging from $20-25^{\circ} \mathrm{C}$. Depending on treatment, the upper tensiometer reached the air entry value after 5-11 days. At the end of experiment, soil samples were oven dried at $105^{\circ} \mathrm{C}$ for $24 \mathrm{~h}$.

The bimodal version of the van Genuchten model, BVGM (van Genuchten, 1980), as described by Durner (1994), was adopted to model soil water retention:

$$
Q(h)=Q_{r}+\frac{\left(Q_{s}-Q_{r}\right) \cdot w}{\left(1+\left(\alpha_{1} h\right)^{n_{1}}\right)^{1-1 / m_{1}}}+\frac{\left(Q_{s}-Q_{r}\right) \cdot(1-w)}{\left(1+\left(\alpha_{2} h\right)^{n_{2}}\right)^{1-1 / m_{2}}},
$$

where: $h$ is water the pressure head $(\mathrm{cm}) ; \theta, \theta_{\mathrm{r}}$ and $\theta_{\mathrm{s}}$ are the actual, residual and saturated volumetric water contents $\left(\mathrm{cm}^{3} \mathrm{~cm}^{-3}\right)$, respectively; $\alpha\left(\mathrm{cm}^{-1}\right)$ and $n$ (dimensionless) are the pore size distribution parameters; and $w$ is a weighting factor. Subscripts 1 and 2 denotate porosity subsystems. The bimodal version of the van Genuchten model is recommended for soils with heterogeneous pore systems that cannot be adequately described by the unimodal version of the van Genuchten model (Eq. (1) with $w=1$ ) was also used. In the present study, two very different solid materials were mixed, therefore we considered that heterogeneous pore systems should not be disregarded. Both uni- and bi-modal versions of the van Genuchten model were tested and the bimodal alternative were chosen because it provided a better fit to the observations.

For all samples, the initial water content was approximately $1 \%$ less than the porosity, which was probably due to the entrapped air (Dettmann et al., 2014). The van Genuchten SWRC fitting parameters $\theta_{r}, \alpha_{i}$ and $n_{i}$ were obtained by applying the generalized reduced gradient algorithm (Abadie and Carpentier, 1968; Lasdon et al., 1978), to minimize the sum of the root mean square error between the observed and predicted values. The FC and the PWP were considered as the soil water contents at the water potential equal to 10 and $1500 \mathrm{kPa}$, respectively (Mylavarapu and Zinati, 2009; Jeffery et al., 2015).

The pore size distribution (PSD) was quantified following two different approaches. First approach uses the fitted parameters for the BVGM obtained from the SWRC fitting process (above mentioned) and the Jurin's law (Eq. (2)) to relate the soil water pressure head and the soil pore sizes. The Jurin's law is based on the Young-Laplace equation:

$$
h=\frac{-2 \sigma \cos \theta}{\rho_{w} g r},
$$

where: $\theta$ is the contact angle between the soil porous and the water (assumed equal to $0^{\circ}$ in this study); $\sigma$ is the water surface tension $\left(\mathrm{N} \mathrm{m}^{-1}\right)$; $\rho_{\mathrm{w}}$ is the density of water $\left(\mathrm{kg} \mathrm{m}^{-3}\right)$; $g$ is the gravity acceleration $\left(\mathrm{m} \mathrm{s}^{-2}\right) ; r$ is the pore radius (m); and $h$ is the absolute value of the soil water pressure head $(\mathrm{m})$. The pore distribution density was then obtained indirectly.

The second approach to obtain the pore size distribution uses the mercury intrusion porosimetry (MIP) technique and the Washburn's equation, based on the Young-Laplace equation, to later transform the results of MIP into soil pore sizes. The pressure is inversely proportional to the size of the pores, and only slight pressure is required for mercury to intrude into large macropores, whereas much greater pressure is required to force mercury into small pores. In porous medium, mercury intrusion is similar to air injection in a saturated soil in the drying process of a water retention curve (Prapaharan et al., 1987; Romero et al., 1999; Aung et al., 2001; Simms and Yanful, 2001; Zhang and Li, 2010; Mascarenha et al., 2011; Otalvaro et al., 2016). A PoreMaster 60 GT (Quantachrome Instruments) mercury porosimeter was used, and a surface tension and contact angle of mercury of $480 \mathrm{mN} \mathrm{m}^{-1}$ and $130^{\circ}$, respectively, were chosen. The pore diameter interval ranged from 0.002 to $200 \mu \mathrm{m}$, which corresponds to the highest (410 MPa) and lowest $(1 \mathrm{kPa})$ head pressures. The samples were analyzed after determination of the saturated hydraulic conductivity and the soil water retention curve tests.

Microstructural characterization was performed using scanning electron microscopy (SEM), which permits the observation of the soil structure and provides clues to understand and explain the observed changes in soil hydraulic properties. Samples were observed in low-vacuum mode (voltage of 5-30 keV) with a Hitachi S3000N microscope. SEM images were taken at 50x magnification. At this low magnification, the low-vacuum mode provides excellent images without coating the sample. The samples were analyzed after the saturated hydraulic conductivity and soil water retention curve measurements. The samples were laterally sealed to obtain undisturbed samples and then were placed in the holder for analysis.

Soil hydraulic properties were analyzed using the SPSS 24 statistical package. Treatment means were compared by using Duncan's test at a significant level of $p<0.05$ and $\mathrm{p}<0.01$.

\section{RESULT AND DISCUSSION}

Selected physical and mineralogical properties of the original sandy soil and marble powder are presented in Table 1. Content of selected heavy metals by the EU 2015/2099 Decision (European Union, 2015) was always below the maximum limits (Table 2) and was even below the detection limit or just non-detected in three out of seven target heavy metals. 
Table 1. Physical and mineralogical properties of the original sandy soil and the marble powder

\begin{tabular}{|c|c|c|c|c|c|c|c|c|c|c|}
\hline \multirow{2}{*}{ Samples } & \multirow{2}{*}{ Sand } & Silt & Clay & \multirow{2}{*}{ Texture } & Bulk & Particle & \multicolumn{4}{|c|}{ Mineral composition (\%) } \\
\hline & & $(\%)$ & & & & & Calcite & Dolomite & Quartz & Feldspar \\
\hline Soil & 88.0 & 5.0 & 7.0 & $\begin{array}{l}\text { Loamy } \\
\text { sand }\end{array}$ & 1.62 & 2.62 & 17 & - & 61 & 22 \\
\hline Marble & 0.0 & 57.7 & 42.3 & Silty clay & - & 2.67 & 63 & 36 & 1 & - \\
\hline
\end{tabular}

Table 2. Content of heavy metals in the marble powder and limits of these components according to EU 2015/2099 Decision

\begin{tabular}{lcc}
\hline Elements & EU limits & Marble powder \\
\hline Cadmium $(\mathrm{Cd})$ & 3 & 0.16 \\
Chromium total $(\mathrm{Cr})$ & 150 & 3.0 \\
Copper $(\mathrm{Cu})$ & 100 & 6.2 \\
Mercury $(\mathrm{Hg})$ & 1 & $\mathrm{NA}$ \\
Nickel $(\mathrm{Ni})$ & 90 & 1.5 \\
Lead $(\mathrm{Pb})$ & 150 & 2.4 \\
Zinc $(\mathrm{Zn})$ & 300 & 6.0 \\
\hline NA - not analyzed. & &
\end{tabular}

The percentage of sand in the amended soil decreased jointly with an increase in clay and specially in silt. Percentages passed from 88/5/7 (sand/silt/clay) to 65-7/18.4/ 15.9 for the M0 and M25 treatments respectively (Table 3). Since the marble powder was added under the premise of keeping the pore volume constant, the bulk density varied slightly among the different treatments because of the different values in the soil particle density between sandy soil and marble powder (Table 3 ).

The saturated hydraulic conductivity (Table 4) decreased after marble addition for all treatments. Compared to the control (M0), the marble powder application decreased the saturated hydraulic conductivity by $83,90,93,95$ and $97 \%$ for M5, M10, M15, M20, and M25, respectively. Barnes et al. (2014), who studied soil amendment by biochar, also reported that using $140 \mathrm{t} \mathrm{ha}^{-1}$ biochar decreased sandy soil's saturated hydraulic conductivity by $92 \%$. Volk et al. (2016) also found that biofilm amended sandy soil reduced the saturated hydraulic conductivity.

The fitted parameters from the BVGM (Eq. (1)) for all six treatments are shown in Table 4 and Fig. 1. Additionally, the soil water retention data for the three replications and six treatments jointly, with the fitting curves from the bimodal and unimodal van Genuchten models were included in

Table 3. Percentage of sand, clay and silt (mass-based), bulk density and texture

\begin{tabular}{lcccccc}
\hline \multirow{2}{*}{ Soil property } & \multicolumn{7}{c}{ Treatments } \\
\cline { 2 - 7 } & M0 & M5 & M10 & M15 & M20 & M25 \\
\hline Sand & 88 & 83.5 & 79.1 & 74.6 & 70.1 & 65.7 \\
Silt & 5.0 & 7.7 & 10.3 & 13.0 & 15.7 & 18.4 \\
Clay & 7 & 8.8 & 10.6 & 12.4 & 14.2 & 15.9 \\
Bulk density $\left(\mathrm{g} \mathrm{cm}^{-3}\right)$ & 1.619 & 1.621 & 1.622 & 1.624 & 1.625 & 1.626 \\
Texture & Loamy sand & Loamy sand & Sandy loam & Sandy loam & Sandy loam & Sandy loam \\
\hline
\end{tabular}

Table 4. Saturated hydraulic conductivity and van Genuchten soil-water characteristic curve fitting parameters

\begin{tabular}{cccccccc}
\hline \multirow{2}{*}{ Parameters } & \multicolumn{9}{c}{ Treatments } & \multirow{2}{*}{ ANOVA } \\
\cline { 2 - 5 } & M0 & M5 & M10 & M15 & M20 & M25 & \\
\hline $\mathrm{K}_{\text {sat }}\left(\mathrm{cm} \mathrm{day}^{-1}\right)$ & $117.5^{\mathrm{a}+}$ & $20.1^{\mathrm{b}}$ & $12.0^{\mathrm{bc}}$ & $7.7^{\mathrm{bc}}$ & $6.1^{\mathrm{c}}$ & $3.4^{\mathrm{c}}$ & $* *$ \\
$\theta_{s}(\%)$ & $33.7^{\mathrm{a}}$ & $35.1^{\mathrm{a}}$ & $34.3^{\mathrm{a}}$ & $34.0^{\mathrm{a}}$ & $33.7^{\mathrm{a}}$ & $34.0^{\mathrm{a}}$ & ns \\
$\theta_{r}(\%)$ & $4.5^{\mathrm{b}}$ & $6.3^{\mathrm{b}}$ & $6.4^{\mathrm{b}}$ & $7.5^{\mathrm{ab}}$ & $8.2^{\mathrm{ab}}$ & $12.1^{\mathrm{a}}$ & $*$ \\
$\alpha_{1}$ & $0.017^{\mathrm{a}}$ & $0.016^{\mathrm{a}}$ & $0.015^{\mathrm{a}}$ & $0.015^{\mathrm{a}}$ & $0.013^{\mathrm{ab}}$ & $0.011^{\mathrm{b}}$ & $* *$ \\
$n_{1}$ & $4.5^{\mathrm{a}}$ & $2.3^{\mathrm{b}}$ & $1.7^{\mathrm{b}}$ & $1.6^{\mathrm{b}}$ & $1.6^{\mathrm{b}}$ & $1.6^{\mathrm{b}}$ & $*$ \\
$w$ & $0.49^{\mathrm{a}}$ & $0.51^{\mathrm{a}}$ & $0.61^{\mathrm{a}}$ & $0.64^{\mathrm{a}}$ & $0.63^{\mathrm{a}}$ & $0.61^{\mathrm{a}}$ & $\mathrm{ns}$ \\
$\alpha_{2}$ & $0.018^{\mathrm{a}}$ & $0.017^{\mathrm{ab}}$ & $0.015^{\mathrm{ab}}$ & $0.015^{\mathrm{ab}}$ & $0.015^{\mathrm{ab}}$ & $0.014^{\mathrm{b}}$ & $*$ \\
$n_{2}$ & $5.6^{\mathrm{a}}$ & $5.2^{\mathrm{a}}$ & $5.0^{\mathrm{a}}$ & $4.8^{\mathrm{a}}$ & $4.6^{\mathrm{a}}$ & $4.3^{\mathrm{a}}$ & $\mathrm{ns}$ \\
\hline
\end{tabular}

+Values in the same row with the same letter are not significantly different at $\mathrm{p}<0.05$ level. Statistically significant at: $* 5 \%$ level, $* * 1 \%$ level. 


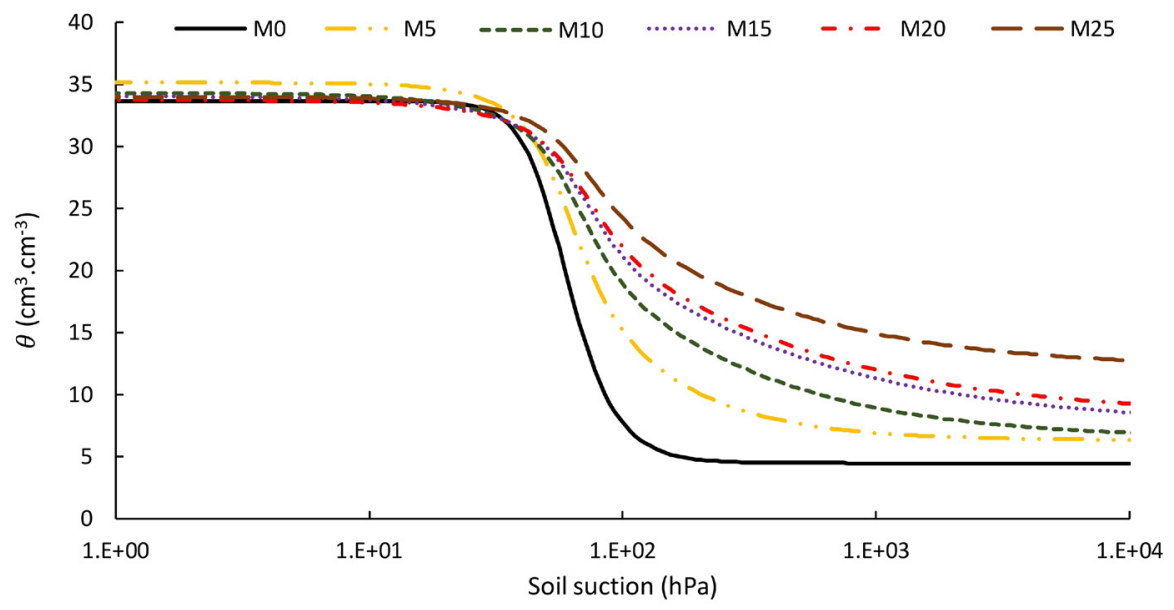

Fig. 1. Average soil water retention curves for the original soil and the five levels of marble additions. The numbers indicate the percentage of marble powder added to the original sandy soil.

the Supplementary Material file (Fig. S1). Both uni- and bimodal options provided a good fit during the wet and middle parts of the curves; nevertheless, the bimodal option was more flexible and better fitted the dry part, with the pressure head below $200 \mathrm{hPa}$, so the bimodal option results were selected and further discussed. The $\theta_{s}$ parameter showed only slight differences that were not statistically significant. These differences could be attributed to process errors, because all the mixtures were initially designed to have the same total porosity. Regarding the residual water content $\left(\theta_{r}\right)$, a monotonic and statistically significant increase was observed with increasing percentages of marble addition, which can be explained by the increase in the percentage of fine soil particles and then the increase in the specific surface of the mixture. The increment in $\theta_{r}$ was more pronounced in M15, M20 and M25. The $\theta_{r}$ in M25 was approximately three times higher than that of the original sandy soil. Addition of marble powder more than $10 \%$ changed the soil texture from sandy loam to loamy sand.
The shape parameter $\alpha$ decreased significantly and monotonically with marble powder addition from 0.018 to $0.013\left(\mathrm{~cm}^{-1}\right)$ for the original sandy soil and M25, respectively. Parameter $\alpha$ is related to the air entry pressure (Peters and Durner, 2008); the lower $\alpha$ is, the higher the air entry pressure becomes. The addition of marble powder significantly increased the air entry pressure. Parameter $\alpha$ also determines the position of the maximum pore density (Durner, 1994), which decreased with the increase of marble powder (Figs 2 and 3).

Parameter $n$ is related to the pore size distribution; the narrower the pore size distribution is, the larger the $n$ (Peters and Durner, 2008). The average fitted SWRCs (Fig. 1) shows the impact of those parameter changes (Jury and Horton, 2004). The figure also shows the original SWRC (black line) and the SWRCs for all levels of marble powder addition. All the above-mentioned comments are graphically collected in the figure, which shows the gradual evolution of curves with more gradual transitions between

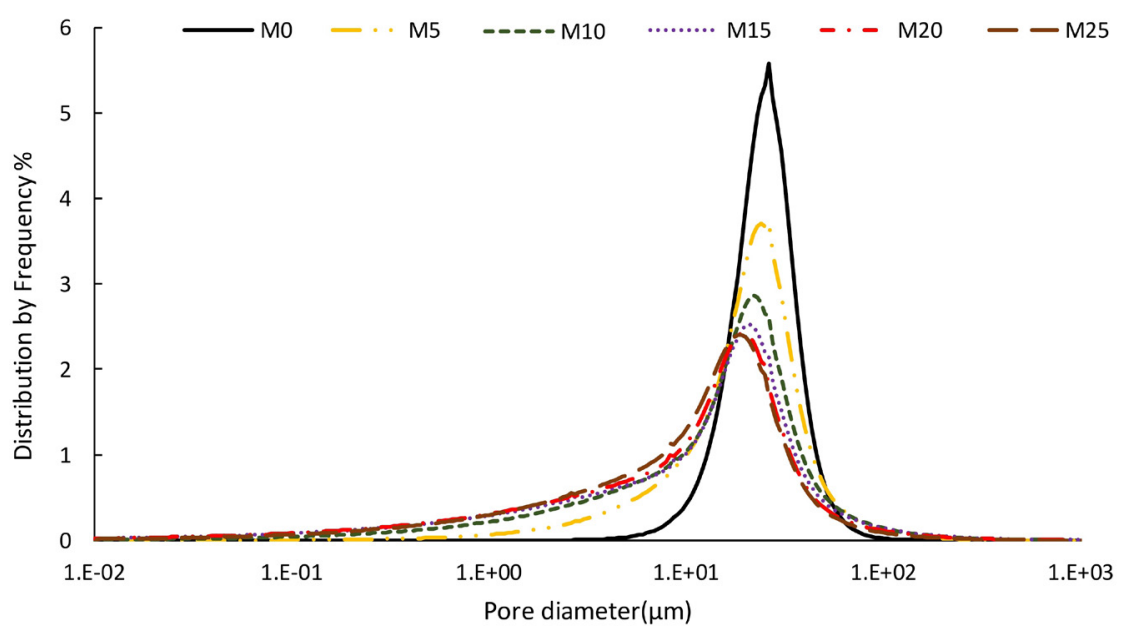

Fig. 2. Pore size density functions from the van Genuchten model parameters for the different treatments. 


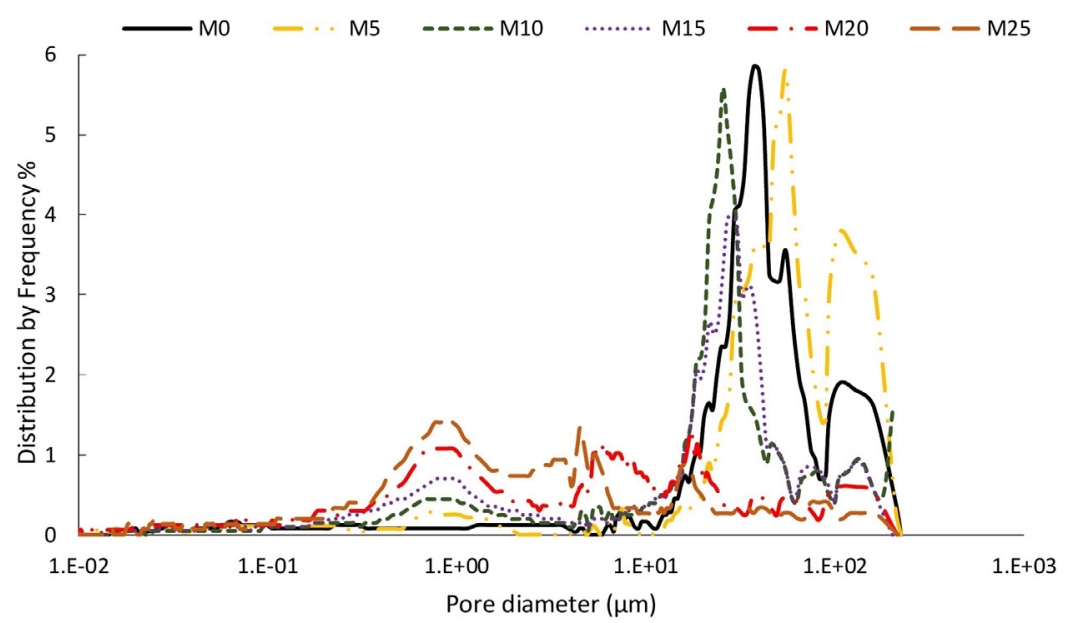

Fig. 3. Pore size distribution curves from mercury intrusion porosimetry for different treatments.

the higher and lower water contents. The sandy soil, which had higher percentages of large pores and a smaller range of pores, yielded curves with substantial decreases of water content in relatively narrow ranges of the soil pressure head. In marble-powder-amended soils, this feature was modified by producing a wider range of pore sizes (Figs 2 and 3), which caused a gradual reduction of potential gradient during the drying of the sample, thus indicating that narrow pores are more frequent. By keeping the total porosity constant, potential differences among samples should be attributed to differences in the grain size distribution, which causes changes in the pore size distribution. By increasing the percentage of marble powder in the mixture, the percentage of very small pores increased and marble powder blocked the larger soil pores, which mainly contribute to a large proportion of the water flux in the soil.

The root mean square error (RMSE) for SWRC obtained using Hyprop and fitted SWRC with the bimodal version of the van Genuchten model (Table 5) indicated that the fit was acceptable as the reported average RMSE values for all fittings were equal to $2 \%$ and always below $4 \%$; these values are similar to the errors of typical soil moisture measurement reported by the industry (Decagon Devices Inc, 2010; Campbell Scientific, 2012).

PSD obtained using the fitted parameters from the BVG model and the Jurin's law (Fig. 2) revealed that the addition of marble powder to sandy soil reduced the mean

Table 5. RMSE between observed and simulated soil pressure head for all treatments and replications considering the bimodal van Genuchten model (Eq. (1))

\begin{tabular}{ccccccc}
\hline $\begin{array}{c}\text { Replica- } \\
\text { tions }\end{array}$ & M0 & M5 & M10 & M15 & M20 & M25 \\
\hline 1 & 0.03 & 0.02 & 0.01 & 0.02 & 0.02 & 0.02 \\
2 & 0.04 & 0.03 & 0.02 & 0.01 & 0.02 & 0.02 \\
3 & 0.02 & 0.02 & 0.02 & 0.02 & 0.01 & 0.01 \\
\hline
\end{tabular}

pore size, and increased the spread of pore sizes, i.e., with marble powder addition the soil presented a larger more extended range of pore sizes. The most important increase in the spread of pores sizes appeared with additions of low percentages ( 5 and 10\%); on the other hand, the differences in the pore size distributions for the M20 and M25 treatments were insignificant. The PSD obtained from the second approach, using the MIP technique (Fig. 3), shows that M0 had most of pores in the pore diameter interval of 10-200 $\mu \mathrm{m}$, and the dominant (i.e. the most frequent) pore diameter in M0 was approximately $40 \mu \mathrm{m}$. The increase in added marble powder produced a monotonic reduction in the dominant pore diameter, with additions equal or higher than $10 \%$. In the case of $5 \%$ of addition, there was not detected a clear reduction in the dominant pore size. In general, the dominant pore diameter decreased from $40 \mu \mathrm{m}$ in M0 to $1 \mu \mathrm{m}$ in M20 and M25. Focusing on the complete pore size spectrum besides the dominant size, M0 can be defined as a single grain structure (sorted soil); nevertheless, the M5 to M25 treatments produced bimodal pore size distributions. Results demonstrates that the percentage of pores in the $0.5-10 \mu \mathrm{m}$ interval increased with the marble powder addition (Fig. 3).

There is relatively good agreement between the pore size distributions obtained from water retention and from mercury porosimetry. Both methods resulted in the dominant pore size in the range $30-50 \mu \mathrm{m}$ for the original sandy soil, and both considered that the pore distribution density moved to smaller pore sizes with the increasing addition of marble powder. The dominant pore diameter for M20 and M25, inferred from the fitted parameters (first approach) was higher than the value that was reported by the MIP data. The most important disagreement between the two methods was the presence of two families of dominant pores in MIP results but not in SWRC data. The width of the PSD obtained from SWRC moved toward a fine pore size with the increasing addition of marble powder. This disagree- 
ment in the presence of one or two families of dominant pores was more pronounced with the highest percentage of marble powder addition. The different scales that both methods operate at, with distinctly smaller samples in the case of MIP compared to the sample size that is needed for the Hyprop apparatus, could explain this disagreement. Romero et al. (1999) reported that the MIP predictions significantly underestimated the water contents of a clay soil at suctions higher than $400 \mathrm{hPa}$, which occurred at pore diameters smaller than $7 \mu \mathrm{m}$. The good fit obtained using the unimodal van Genuchten (Supplementary Material file) showed that the bimodal structure of the pore size distribution was not expressed well in the soil water retention curve.

Both FC and the PWP increased with the increasing addition of marble powder. Nevertheless, the increasing trend was different between FC and PWP and as a consequence PAW, obtained as the difference between field capacity and permanent wilting point, showed a maximum value of $12.73 \%$ with marble powder percentages of $15 \%$ (Fig. 4 and Table 6). This result constitutes an increase of $120 \%$ from the value of PAW in the original sandy soil (i.e. $5.78 \%$ for the original soil). The increase in the PAW was more important in the percentages of addition up to $10 \%$ (Fig. 4). Actually, the PAW results from M10, M15, M20 and M25 showed no statistically significant differences. On the contrary, results from M0 and M5 did show statistically significant differences between them and between each of them and the M10-M15-M20-M25 group (Table 5). The PAW is one of the most important parameters in irrigation and drainage system design, and increasing PAW on a large scale could help to save water and energy, very important in water-scarce societies. The results showed that the most

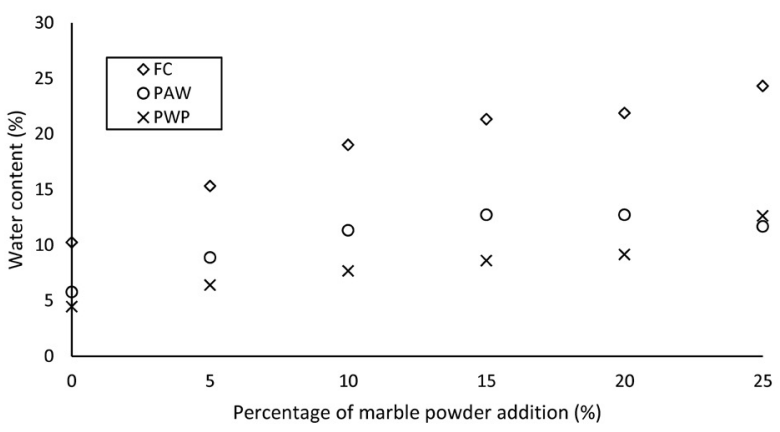

Fig. 4. Field capacity (FC), plant available water (PAW) and permanent wilting point (PWP) for the original soil and the five treatments.

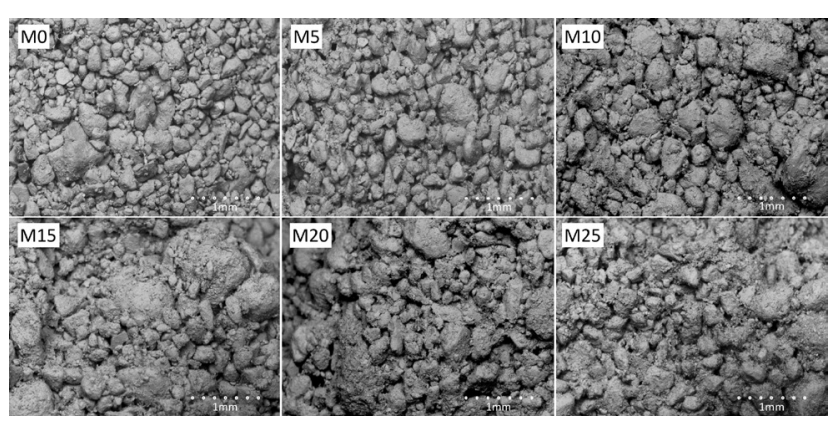

Fig. 5. Scanning electron microscope images for different treatments at the $50 \mathrm{x}$ magnification. The numbers indicate the percentage of marble powder added to the original sandy soil.

promising percentage of addition is $10 \%$ because it leads to the highest increases in PAW with the lowest percentage of marble powder addition.

The SEM results of specimens are shown in Fig. 5. It can be observed that, as the percentages of marble powder in the mixture increase, there is a gradual process of filling of the small pores that are clearly identified in the M25 image but are less common in the M0 image. The soil particles in the original soil (M0) are coated by other much smaller particles increasing the specific surface and providing a graphical explanation for the increase in soil water retention (Fig. 5).

Marble powder appear to be located in the intergrain pores of the original soil, thus reducing the effective space for water flow, which explains the reduction in saturated hydraulic conductivity. As a consequence, marble powder connect the original soil particles together, fills larger pores and creates a finer structure of pores, which also explains the variation in the van Genuchten parameters, field capacity, permanent wilting point and plant available water.

\section{CONCLUSIONS}

Although marble powder-amended soils have been studied before, to the best of our knowledge, this is the first study on the potential improvement of sandy soil hydraulic properties with the addition of marble powder. From our results, we can conclude:

1. A significant decrease in saturated hydraulic conductivity as a result of marble powder addition to sandy soil.

2. The addition of marble powder decreased the soil pore size and had a great impact on the soil water retention behaviour.

Tab le 6. Average field capacity (FC), permanent wilting point (PWP), and plant available water (PAW) for the different treatments

\begin{tabular}{lccccccc}
\hline Treatments & M0 & M5 & M10 & M15 & M20 & M25 & ANOVA \\
\hline FC (\%) & $10.2^{\mathrm{c}+}$ & $15.3^{\mathrm{bc}}$ & $19.0^{\mathrm{ab}}$ & $21.3^{\mathrm{ab}}$ & $21.9^{\mathrm{ab}}$ & $24.3^{\mathrm{a}}$ & $* *$ \\
PWP $(\%)$ & $4.5^{\mathrm{b}}$ & $6.4^{\mathrm{ab}}$ & $7.7^{\mathrm{ab}}$ & $8.6^{\mathrm{ab}}$ & $9.2^{\mathrm{ab}}$ & $12.6^{\mathrm{a}}$ & $* *$ \\
PAW $(\%)$ & $5.8^{\mathrm{c}}$ & $8.9^{\mathrm{b}}$ & $11.3^{\mathrm{a}}$ & $12.7^{\mathrm{a}}$ & $12.7^{\mathrm{a}}$ & $11.7^{\mathrm{a}}$ & $* *$ \\
\hline
\end{tabular}

Explanations as in Table 4. 
3. The range of pore sizes in amended soils increased, and the abrupt changes in the soil water content with small changes of the soil pressure head, which were observed in the original soil, disappeared giving place to more gradual changes in the water content.

4. The bimodal van Genuchten model provided a better fit to the observed water retention data than the unimodal van Genuchten model. However, it is worthy to note that the unimodal model fit was also good and that the main differences appeared in the dry part of the curve, with pressure heads below $-500 \mathrm{hPa}$.

5. The MIP results showed the presence of a wider range of pore sizes in the amended soil and the presence of two main families of pore sizes. This presence of two main families of pore sizes was not surmised from the fitted parameters of the bimodal van Genuchten model.

6 . As the added percentage of marble powder increased, the retention curve moved toward the domain of higher pressure head values, thus increasing the air-entry value. This shift of the soil water retention curve can be attributed to the increment in the pore size range. All $\alpha_{i}$ and $n_{i}$, parameters from the van Genuchten model, decreased in the marble-amended soil.

7. The permanent wilting point and the field capacity significantly increased. Nevertheless, the increase trend in field capacity was different than that for the permanent wilting point, and therefore the plant-available water significantly increased up to $15 \%$ percentage and showed a reduction trend with higher percentage of additions; it was not detected significant difference in the PAW for the percentages of $10,15,20$ and $25 \%$. This improvement in the plant available water provides a potential benefit for agriculture management in water-scarce environments.

7. Since the statistically significant differences for PAW occurred with percentages of addition below $10 \%$, further investigation should focus on the impact of lower percentages of the marble powder additions. Investigating the impact of adding lower percentages of marble powder could assist in determining the optimum percentage of marble powder to improve sandy soils across large areas.

Further studies, especially under field conditions, should be conducted to investigate the effect of marble addition on sandy soil hydraulic properties on a larger scale.

Conflict of interest: The Authors do not declare conflict of interest.

\section{REFERENCES}

Abadie J. and Carpentier J., 1968. Generalization of the wolfe reduced gradient method to the case of nonlinear constraints In: Optimization (Ed. R. Fletcher). Academic Press, New York.

Amoakwah E., Frimpong K.A., Okae-Anti D., and Arthur E., 2017. Soil water retention, air flow and pore structure characteristics after corn cob biochar application to a tropical sandy loam. Geoderma, 307: 189-197.

https://doi.org/10.1016/j.geoderma.2017.08.025
Ashish D.K., 2018. Feasibility of waste marble powder in concrete as partial substitution of cement and sand amalgam for sustainable growth. J. Build Eng., 15: 236-242.

https://doi.org/10.1016/j.jobe.2017.11.024

Auler A.C., Pires L.F., and Caires E.F., 2017. Surface and incorporated liming effects on clay dispersion, water availability, and aeration capacity of a dystrudept soil. Bragantia, 76: 433-446. https://doi.org/10.1590/1678-4499.290

Aung K.K., Rahardjo H., Leong E.C., and Toll D.G., 2001. Relationship between porosimetry measurement and soilwater characteristic curve for an unsaturated residual soil. Geotech. Geol. Eng., 19, 401-416. https://doi.org/10.1007/978-94-015-9775-3_9

Banedjschafie S. and Durner W., 2015. Water retention properties of a sandy soil with superabsorbent polymers as affected by aging and water quality. J. Plant Nutr. Soil Sci., 178: 798-806. https://doi.org/10.1002/jpln.201500128

Barnes R.T., Gallagher M.E., Masiello C.A., Liu Z., and Dugan B., 2014. Biochar-induced changes in soil hydraulic conductivity and dissolved nutrient fluxes constrained by laboratory experiments. PLoS ONE. 9. https://doi.org/10.1371/journal.pone.0108340

Barros M.C., Bello P.M., Bao M., and Torrado J.J., 2009. From waste to commodity: Transforming shells into high purity calcium carbonate. J. Clean Prod., 17: 400-407. https://doi.org/10.1016/j.jclepro.2008.08.013

Basso A.S., Miguez F.E., Laird D.A., Horton R., and Westgate M., 2013. Assessing potential of biochar for increasing water-holding capacity of sandy soils. GCB Bioenergy, 5: 132-143. https://doi.org/10.1111/gcbb.12026

Biddau R., Cidu R., Da Pelo S., Carletti A., Ghiglieri G., and Pittalis D., 2019. Source and fate of nitrate in contaminated groundwater systems: Assessing spatial and temporal variations by hydrogeochemistry and multiple stable isotope tools. Sci. Total Environ., 647: 1121-1136.

https://doi.org/10.1016/j.scitotenv.2018.08.007

Brown A.L., Nielsen Tr., and Halevy E., 1959. Lime effect on soil properties studies made on the effect of massive lime application on physical properties of five types of Sacramento Valley soils. California Agric., 34: 281-284.

Campbell Scientific I., 2012. Cs650 and cs655 water content reflectometers. Campbell Scientific, Inc., Logan, UT, USA).

da Costa C.H.M. and Crusciol C.A.C., 2016. Long-term effects of lime and phosphogypsum application on tropical no-till soybean-oat-sorghum rotation and soil chemical properties. Eur. J. Agron., 74: 119-132. https://doi.org/10.1016/j.eja.2015.12.001

Decagon Devices Inc., 2010. 5te operator manual. Version 6. Decagon Devices Inc, Pullman, WA, USA).

Dettmann U., Bechtold M., Frahm E., and Tiemeyer B., 2014. On the applicability of unimodal and bimodal van Genuchten-Mualem based models to peat and other organic soils under evaporation conditions. J. Hydrol., 515: 103115. https://doi.org/10.1016/j.jhydrol.2014.04.047

Durner W., 1994. Hydraulic conductivity estimation for soils with heterogeneous pore structure. Water Resour Res., 30: 211-223. https://doi.org/10.1029/93wr02676

Eibisch N., Durner W., Bechtold M., Fuß R., Mikutta R., Woche S.K., and Helfrich M., 2015. Does water repellency of pyrochars and hydrochars counter their positive effects on soil hydraulic properties? Geoderma, 245-246: 31-39. https://doi.org/10.1016/j.geoderma.2015.01.009 
European Union, 2015. Commission decision (EU) 2015/2099 of 18 November 2015 establishing the ecological criteria for the award of the EU ecolabel for growing media, soil improvers and mulch.

Flint A.L. and Flint L.E., 2002a. Particle density. In: Methods of soil analysis. Part 4. Physical Methods (Eds J. Dane, C. Topp). Soil Sci. Soc. America, Madison, WI, USA. https://doi.org/10.2136/sssabookser5.4.c10

Flint L.E. and Flint A.L., 2002b. Porosity. In: Methods of Soil Analysis. Part 4. Physical Methods (Eds J. Dane, C. Topp). Soil Science Society of America, Madison, WI, USA. https://doi.org/10.2136/sssabookser5.4.c11

Gee G.W. and Or D., 2002. Particle-size analysis. In: Methods of Soil Analysis. Part 4. Physical Methods (Eds J. Dane, C. Topp). Soil Science Society of America, Madison, WI, USA. https://doi.org/10.2136/sssabookser5.4.c12

Ghodrati M., Sims J.T., and Vasilas B.L., 1995. Evaluation of fly ash as a soil amendment for the atlantic coastal plain: I. Soil hydraulic properties and elemental leaching. Water Air Soil Pollut., 81: 349-361. https://doi.org/10.1007/bf01104020

Grossman R.B. and Reinsch T.G., 2002. Bulk density and linear extensibility. In: Methods of Soil Analysis Part 4. Physical Methods (Eds J. Dane, C. Topp). Soil Science Society of America, Madison, WI, USA.

https://doi.org/10.2136/sssabookser5.4.c9

Hall D.J.M. and Bell R.W., 2015. Biochar and compost increase crop yields but the effect is short term on sandplain soils of Western Australia. Pedosphere, 25: 720-728. https://doi.org/10.1016/s1002-0160(15)30053-9

Holland J.E., Bennett A.E., Newton A.C., White P.J., McKenzie B.M., George T.S., Pakeman R.J., Bailey J.S., Fornara D.A., and Hayes R.C., 2018. Liming impacts on soils, crops and biodiversity in the UK: A review. Sci. Total Environ., 610-611: 316-332.

https://doi.org/10.1016/j.scitotenv.2017.08.020

Jeffery S., Meinders M.B.J., Stoof C.R., Bezemer T.M., van de Voorde T.F.J., Mommer L., and van Groenigen J.W., 2015. Biochar application does not improve the soil hydrological function of a sandy soil. Geoderma, 251-252: 47-54. https://doi.org/10.1016/j.geoderma.2015.03.022

Joris H.A.W., Caires E.F., Bini A.R., Scharr D.A., Haliski A., 2013. Effects of soil acidity and water stress on corn and soybean performance under a no-till system. Plant Soil, 365: 409-424. https://doi.org/10.1007/s11104-012-1413-2

Jury W.A. and Horton R., 2004. Soil Physics. Wiley, Mexico.

Khodabakhshian A., de Brito J., Ghalehnovi M., Asadi Shamsabadi and E., 2018. Mechanical, environmental and economic performance of structural concrete containing silica fume and marble industry waste powder. Construction and Building Materials, 169: 237-251. https://doi.org/10.1016/j.conbuildmat.2018.02.192

Lasdon L.S., Waren A.D., Jain A., and Ratner M., 1978. Design and testing of a generalized reduced gradient code for nonlinear programming. ACM Trans. Math. Softw., 4: 34-50. https://doi.org/10.1145/355769.355773

Marras G., Careddu N., Internicola C., and Siotto G., 2010. Recovery and reuse of marble powder by-product.

Martin Ramos J.D., 2004. Using xpowder: A software package for powder x-ray diffraction analysis (Ed. J.D. Martin Ramon). Granada, Spain.
Mascarenha M.M.A., Cordão-Neto M.P., and Romero E., 2011. Influence of the microstructure on the hydro-mechanical behaviour of a natural silty clay. Proc. 5th Int. Conference on Unsaturated Soils (Eds E. Alonso, A. Gens), 167-172. https://doi.org/10.1201/b10526-16

Mylavarapu R.S. and Zinati G.M., 2009. Improvement of soil properties using compost for optimum parsley production in sandy soils. Sci. Hortic., 120: 426-430. https://doi.org/10.1016/j.scienta.2008.11.038

Olego M.A., Visconti F., Quiroga M.J., de Paz J.M., and Garzón-Jimeno E., 2016. Assessing the effects of soil liming with dolomitic limestone and sugar foam on soil acidity, leaf nutrient contents, grape yield and must quality in a mediterranean vineyard. Span. J. Agric. Res., 14. https://doi.org/10.5424/sjar/2016142-8406

Otalvaro I.F., Neto M.P.C., Delage P., and Caicedo B., 2016. Relationship between soil structure and water retention properties in a residual compacted soil. Eng. Geol., 205: 73-80. https://doi.org/10.1016/j.enggeo.2016.02.016

Peters A. and Durner W., 2008. Simplified evaporation method for determining soil hydraulic properties. J. Hydrol., 356: 147-162. https://doi.org/10.1016/j.jhydrol.2008.04.016

Porter S.N., Humphries M.S., Buah-Kwofie A., and Schleyer M.H., 2018. Accumulation of organochlorine pesticides in reef organisms from marginal coral reefs in South Africa and links with coastal groundwater. Mar. Pollut. Bull., 137: 295-305. https://doi.org/10.1016/j.marpolbul.2018.10.028

Prapaharan S., Altschaeffl A.G., and Dempsey B.J., 1987. Moisture curve of compacted clay: Mercury intrusion method. J. Geotech. Eng., 113: 822-823. https://doi.org/10.1061/(asce)0733-9410(1987)113:7(822)

Qi F., Kunihiko E., and Guodong C., 2002. Soil water and chemical characteristics of sandy soils and their significance to land reclamation. J. Arid Environ., 51: 35-54. https://doi.org/10.1006/jare.2001.0928

Ratke R.F., Pereira H.S., De Deus Gomes Dos Santos Júnior J., Barbosa J.M., and Lopes L.O., 2018. Different limestone particle sizes for soil acidity correction, $\mathrm{Ca}$ and $\mathrm{Mg}$ supply and corn yield. Comun Sci., 9: 175-184. https://doi.org/10.14295/cs.v9i2.2205

Remonsellez F., Zarrias N., Bol R., and Fuentes B., 2017. Characterization and low-cost treatment of an industrial arid soil polluted with lead sulfide in Northern Chile. Environ. Earth Sci., 76. https://doi.org/10.1007/s12665-017-6617-6

Romero E., 1999. Characterisation and thermo-hydro-mechanical behaviour of unsaturated Boom clay: An experimental study. Polytechnic University of Catalonia.

Romero E., Gens A., and Lloret A., 1999. Water permeability, water retention and microstructure of unsaturated compacted boom clay. Engineering Geology, 54: 117-127. https://doi.org/10.1016/s0013-7952(99)00067-8

Schindler U., Durner W., von Unold G., Mueller L., and Wieland R., 2010. The evaporation method: Extending the measurement range of soil hydraulic properties using the air-entry pressure of the ceramic cup. J. Plant Nutr. Soil Sci., 173: 563-572. https://doi.org/10.1002/jpln.200900201

Schindler U., Durner W., Von Unold G., and Müller L., 2010. Evaporation method for measuring unsaturated hydraulic properties of soils: Extending the measurement range. Soil Sci. Soc. Am. J., 74: 1071-1083. https://doi.org/10.2136/sssaj2008.0358 
Serio F., Miglietta P.P., Lamastra L., Ficocelli S., Intini F., De Leo F., and De Donno A., 2018. Groundwater nitrate contamination and agricultural land use: A grey water footprint perspective in southern apulia region (Italy). Sci. Total Environ., 645: 1425-1431. https://doi.org/10.1016/j.scitotenv.2018.07.241

Simms P.H. and Yanful E.K., 2001. Measurement and estimation of pore shrinkage and pore distribution in a clayey till during soil-water characteristic curve tests. Can. Geotech. J., 38: 741-754. https://doi.org/10.1139/t01-014

Stone D.A., 1980a. Effects of fine-particle amendments on the hydraulic properties of coarse soils. J. Sci. Food Agric., 31: 750-758. https://doi.org/10.1002/jsfa.2740310803

Stone D.A., 1980b. Effects of textural amendment of coarse soils on crop growth and water use. J. Sci. Food Agric., 31: 769776. https://doi.org/10.1002/jsfa.2740310805

Tiritan C.S., Büll L.T., Crusciol C.A.C., Carmeis Filho A.C.A., Fernandes D.M., and Nascente A.S., 2016. Tillage system and lime application in a tropical region: Soil chemical fertility and corn yield in succession to degraded pastures. Soil Till. Res., 155: 437-447. https://doi.org/10.1016/j.still.2015.06.012

van Genuchten M.T., 1980. Closed-form equation for predicting the hydraulic conductivity of unsaturated soils. Soil Sci. Soc. Am. J., 44: 892-898.

https://doi.org/10.2136/ssaj1980.03615995004400050002x
Volk E., Iden S.C., Furman A., Durner W., and Rosenzweig R., 2016. Biofilm effect on soil hydraulic properties: Experimental investigation using soil-grown real biofilm. Water Res. Res., 52: 5813-5828. https://doi.org/10.1002/2016wr018866

Wang Y., Cheng K., Wu W., Tian H., Yi P., Zhi G., Fan J., and Liu S., 2017. Atmospheric emissions of typical toxic heavy metals from open burning of municipal solid waste in China. Atmos Environ., 152: 6-15. https://doi.org/10.1016/j.atmosenv.2016.12.017

Yunusa I.A.M., Manoharan V., Odeh I.O.A., Shrestha S., Skilbeck C.G., and Eamus D., 2011. Structural and hydrological alterations of soil due to addition of coal fly ash. J. Soils Sed., 11: 423-431. https://doi.org/10.1007/s11368-010-0312-5

Zhang J., Chen Q., and You C., 2016. Biochar effect on water evaporation and hydraulic conductivity in sandy soil. Pedosphere, 26: 265-272. https://doi.org/10.1016/s1002-0160(15)60041-8

Zhang L.M. and Li X., 2010. Microporosity structure of coarse granular soils. J. Geotech. Geoenviron. Eng., 136: 14251436. https://doi.org/10.1061/(asce)gt.1943-5606.0000348

Zumrawi M. and Abdalla E., 2018. Stabilization of expansive soil using marble waste powder. 2nd Conf. Civil Engineering, University of Khartoum, Khartoum, Sudan. 


\section{SUPPLEMENTARY MATERIAL}

Impact of marble powder amendment on hydraulic properties of a sandy soil
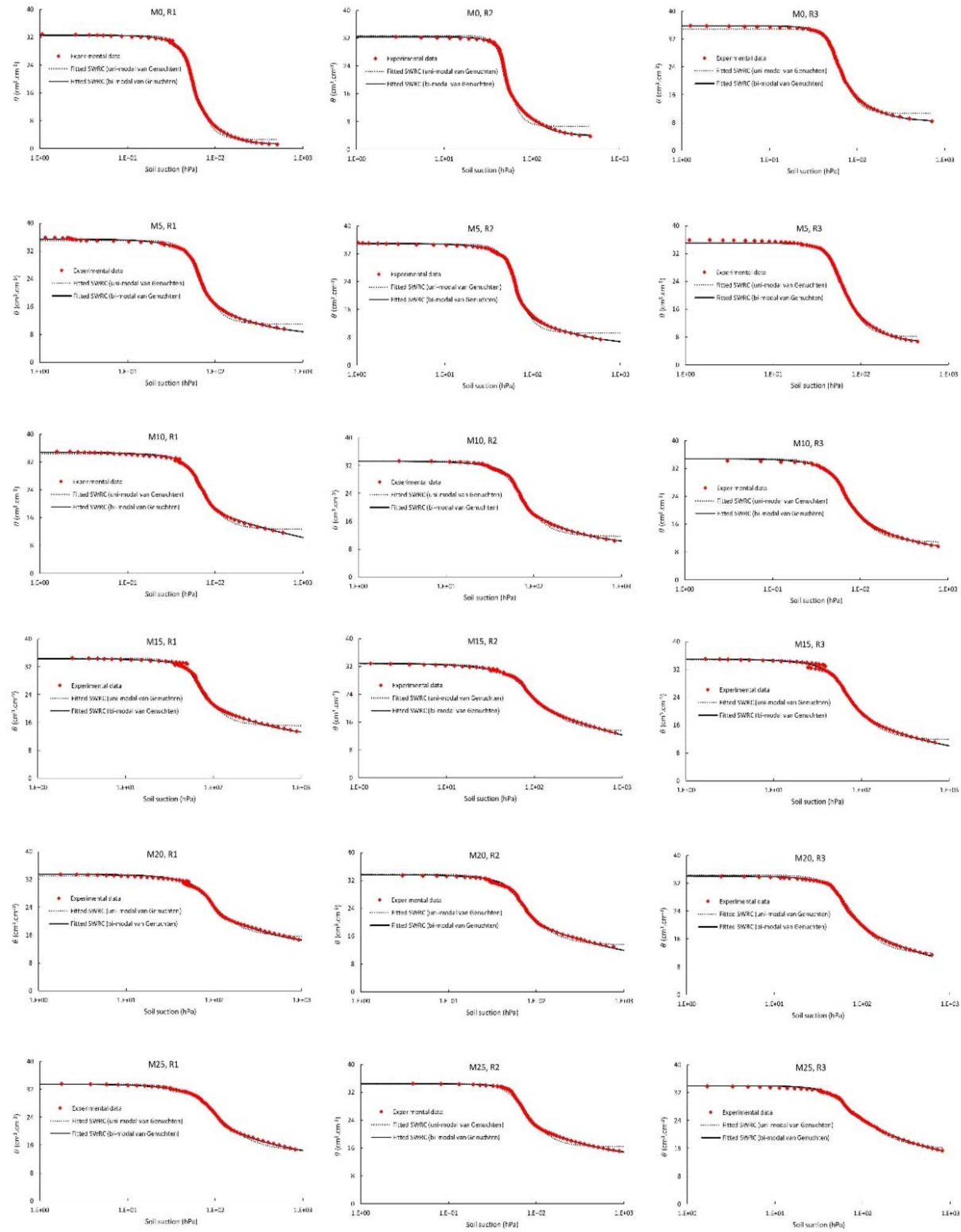

Figure S1. Soil water retention curve data and fitted uni- and bi-modal van Genuchten models for the three replications of the original soil and the five levels of marble. 